\title{
УДК 4414
}

\section{ПРАВОВЫЕ АСПЕКТЫ ПРОВЕДЕНИЯ ОСВИДЕТЕЛЬСТВОВАНИЯ}

\section{Галынина Лидия Ивановна \\ Студент}

Научный руководитель: Ковалев Сергей Евгеньевич

доцент кафедры уголовного права и процесса ФГБОУ ВО «Ивановский государственный университет»

Аннотация: Предпринята попытка дать краткий анализ урегулирования спорных вопросов уголовно-процессуального законодательства, посвященных порядку проведения такого следственного действия как освидетельствование в различных условиях по уголовным делам. Рассматриваются проблемы, которые могут возникнуть в процессе его проведения.

Ключевые слова: уголовный процесс, освидетельствование, проведение следственного действия, принудительный порядок, право на неприкосновенность.

\section{LEGAL ASPECTS OF THE INSPECTION}

\section{Galynina Lidiya Ivanovna} Scientific adviser: Kovalev Sergey Evgenievich

\begin{abstract}
An attempt is made to give a brief analysis of the settlement of controversial issues of criminal procedure legislation, dedicated to the procedure for conducting either an investigative action as examination in various conditions in criminal cases. Problems that may arise in the course of its implementation are considered.

Key words: criminal proceedings, examination, conducting an investigative action, compulsory procedure, the right to immunity.

В теории уголовного процесса вопрос о возможности принудительного освидетельствования является дискуссионным. Актуальность рассматриваемой проблемы и его осуществления в целом обусловлена важностью соблюдения различных правовых принципов, (конституционных и отраслевых), таких как
\end{abstract}


уважения чести и достоинства личности, неприкосновенности личности, охраны прав и свобод человека и гражданина в уголовном судопроизводстве.

Освидетельствование представляет собой типичное невербальное следственное действие, в основе которого лежат закономерности нагляднообразного восприятия фрагментов объективной реальности, элементов вещной обстановки [1, с.100]. Полученные данные являются частью доказательственной базы в уголовном процессе.

Такой подход свидетельствует о явном родстве освидетельствования со следственным осмотром. Но освидетельствование является по своей природе самостоятельным следственным действием в силу специфики его объекта.

В следственной практике встречаются ситуации, когда подозреваемые, обвиняемые, а также иные участники уголовного процесса, такие как потерпевший, свидетель, отказываются пройти освидетельствование или предоставить биологические образцы жизнедеятельности своего организма. При этом доказательства могут быть получены исключительно процессуальным путем на основании уголовно-процессуального законодательства.

Но ч. 5 ст. 56 УПК РФ указывает на то, что такой участник уголовного процесса, как свидетель не может быть принудительно подвергнут освидетельствованию, за исключением случаев, предусмотренных ч. 1 ст. 179 УПК РФ. Ч. 2 ст. 23 ФЗ «О психиатрической помощи и гарантиях прав граждан при ее оказании» (табл. 1).

Таблица 1

\begin{tabular}{|l|l|}
\hline Ч. 1 ст. 179 УПК РФ & $\begin{array}{l}\text { ФЗ «О психиатрической помощи и гарантиях } \\
\text { прав граждан при ее оказании» }\end{array}$ \\
\hline За исключением случаев, когда & Психиатрическое освидетельствование \\
освидетельствование необходимо для & несовершеннолетнего в возрасте до \\
оценки достоверности его показаний. В & пятнадцати лет или больного наркоманией \\
случаях, не терпящих отлагательства, & несовершеннолетнего в возрасте до \\
освидетельствование может быть & шестнадцати лет проводится при наличии \\
произведено до возбуждения уголовного & информированного добровольного согласия на \\
дела. (Целесообразно добавить перечень & его проведение одного из родителей либо \\
таких случаев в УПК РФ, с целью & иного законного представителя, а в отношении \\
законодательного предотвращения & лица, признанного в установленном законом \\
превышения должностных полномочий, & порядке недееспособным, если такое лицо по \\
так как понятие исключительных случаев & своему состоянию не способно дать \\
представилось для некоторых лиц & информированное добровольное согласие, - \\
абстрактным и субъективным). & при наличии информированного \\
& добровольного согласия на проведение \\
& психиатрического освидетельствования \\
\hline
\end{tabular}


Продолжение таблицы 1

\begin{tabular}{|l|l|}
\hline \multirow{5}{*}{} & законного представителя такого лица. В \\
случае возражения одного из родителей либо \\
при отсутстви родителей или иного \\
законного представителя психиатрическое \\
освидетельствование несовершеннолетнего \\
проводится по решению органа опеки и \\
попечительства, которое может быть \\
обжаловано в суд. (В указанном положении \\
закреплены случаи, при которых разрешено \\
проведение освидетельствования по \\
определенным решениям уполномоченных \\
органов для несовершеннолетних лиц, в \\
связи с чем целесообразно рассмотрение \\
вопроса о том, что бы запретить \\
освидетельствование несовершеннолетних \\
лиц без их согласия, если, к примеру, только \\
родители согласились на проведение \\
указанного следственного действия, в целях \\
соблюдения абсолютной охраны принципа \\
неприкосновенности личности).
\end{tabular}

Таким образом, порядок принудительного освидетельствования как следственного действия нуждается в четком законодательном урегулировании в целях исключения неточностей в ходе расследования.

По утверждению доктора юридических наук В.Л. Жбанкова, поскольку законодатель не установил ответственности за отказ от дачи образцов, изымать образцы принудительно в таких случаях следователь не имеет права [2, c.14-15].

Обращаясь к судебной практике ЕСПЧ, мы можем обратить внимание на то, что Европейский суд по правам человека неоднократно признавал нарушением проведение принудительного психиатрического освидетельствования и госпитализации. В качестве примера приведем решение суда по Делу № 74253/17 «Мананников против России».

В 2013 году А.П. Мананников, (бывший депутат Верховного Совета Российской Федерации, сенатор, избранный от Новосибирской области, правозащитник), раскритиковал в своем блоге решение центрального районного суда Новосибирска, признавшего его виновным в оскорблении двух сотрудников ДПС. Против него были возбуждены два уголовных дела - о 
клевете на судью и неуважении к суду. У гражданина изъяли технику, он был отправлен в больницу для прохождения принудительной медикопсихиатрической экспертизы.

По жалобе поданной заявителем, Европейский Суд постановил, что в данном деле были нарушены требования п. 1 ст. 5 Конвенции о защите прав человека и основных свобод (право на свободу и личную неприкосновенность), ст. 1 Протокола N 1 к Конвенции (защита собственности), ст. 2 Протокола N 4 к Конвенции (право на свободу передвижения). Обязал Россию выплатить компенсацию и возместить судебные расходы за принудительную психиатрическую экспертизу.

Таким образом, вынесенным постановлением ЕСПЧ повысил стандарты защиты прав граждан, обосновал необходимость комплексного анализа законодательных норм [3, c.29]. Фактически установил требования к «справедливости» решений суда, закрепил уровень охраны чести и достоинства личности.

Изучение правовых оснований проведения освидетельствования позволяет сделать вывод о том, что прохождение данной процедуры является именно правом физического лица, от которого оно может отказаться, а не обязанностью. [4, с.20].

Также важно и в перспективе затрагивать вопросы, связанные с правомерностью и допустимостью применения принуждения при производстве освидетельствования. Предлагать усовершенствованные варианты статей Уголовно-процессуального кодекса [5, с.137].

Принимать при этом во внимание присутствие основополагающего принципа состязательности в российском уголовном процессе, который призван обеспечить реальность права на защиту, полное и всестороннее исследование обстоятельств дела, обнаружение истины в судебном разбирательстве.

\section{Список литературы}

1. Брагер Д.К. Принудительное проведение освидетельствования и получение образцов для сравнительного исследования: отдельные проблемы // Вестник Томского государственного университета. — 2013. - № 377. — С. 99101.

2. Жбанков В.А. Получение образцов для сравнительного исследования // M. - 1992. - C. 14-15. 
3. Россинский С.Б. Освидетельствование как невербальное следственное действие // Российская юстиция. - 2014. - № 12. - С. 26-29.

4. Торбин Ю.Г. Теория и практика освидетельствования. - СПб. 2004. - $174 \mathrm{c}$.

5. Оганесян А.В. Некоторые вопросы освидетельствования лиц // Современное право. — 2019. — № 11. С. 137-140. 